Edu Consilium: Jurnal BK Pendidikan Islam

Vol. 3, No. 1, 2022, hlm. 38-50

DOI: $10.19105 /$ ec.v1i1.1808

ISSN 2503-3417 (online)

ISSN 2548-4311 (cetak)

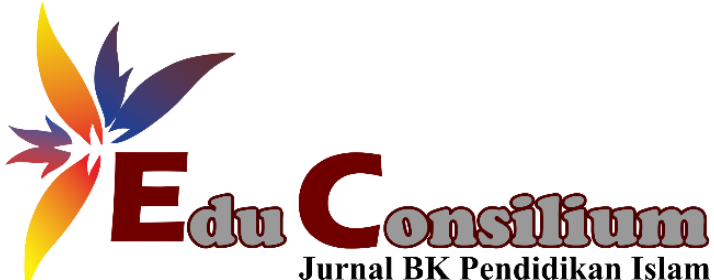

\title{
PENGETAHUAN DAN KETERAMPILAN GURU BK MENGENAI KONSELING MULTIBUDAYA DI INDONESIA
}

\author{
${ }^{1}$ Dwi Ananda Nur Umami \\ ${ }^{1}$ Program Studi Magister Bimbingan dan Konseling, Universitas Negeri Malang, Indonesia \\ dwiananda160198@gmail.com
}

\begin{tabular}{ll}
\hline & Abstract \\
\hline Keywords: & The cultural diversity that exists in Indonesia and is owned by the counselee is very \\
Knowledge of & diverse. The increasing cultural diversity has made BK teachers (counselors) aware of \\
Guidance and & the importance of multicultural awareness in dealing with a difference, no matter how \\
Counseling & small the difference. Counselors are required to have certain competencies or skills to \\
Teachers & carry out their duties properly. One of them is multicultural competence or the \\
Counselor & competence possessed by counselors specifically to understand the cultural diversity of \\
Skills & clients. The purpose of this study is to find out how far the knowledge and skills of BK \\
Multicultural & teachers regarding multicultural counseling, especially in Indonesia it self. The research \\
Counseling & method used is qualitative with an exploratory study design and data collection \\
& techniques using a questionnaire. The result show that the knowledge and skill of \\
& counselors about multicultural counseling in Indonesia is still low. \\
\hline Kata Kunci: & Abstrak \\
Pengetahuan Guru BK & Keanekaragaman budaya yang ada di Indonesia dan dimiliki konseli sangat beragam. \\
Keterampilan & Semakin meningkatnya keragaman budaya tersebut menyadarkan Guru BK (konselor) \\
Konselor & tentang pentingnya kesadaran multikultural dalam menghadapi suatu perbedaan, sekecil \\
Konseling & apapun perbedaan tersebut. Konselor dituntut untuk memiliki kompetensi-kompetensi \\
Multibudaya & atau keterampilan tertentu untuk melaksanakan tugasnya dengan baik. Salah satunya \\
& adalah kompetensi multikultural atau kompetensi yang dimiliki konselor secara khusus \\
& untuk memahami keanekaragaman budaya klien. Tujuan penelitian ini yaitu untuk \\
& mengetahui seberapa jauh pengetahuan dan keterampilan guru BK mengenai konseling \\
& multibudaya terutama di Indonesia sendiri. Metode penelitian yang digunakan yaitu \\
& kualitatif dengan desain studi eksplorasi serta teknik pengumpulan data yaitu \\
& menggunakan angket. Hasilnya menunjukkan pengetahuan dan keterampilan konselor \\
& mengenai konseling multibudaya di Indonesia masih rendah.
\end{tabular}

(CEdu Consilium: Jurnal Bimbingan dan Konseling Pendidikan Islam Institut Agama Islam Negeri Madura, Indonesia

\section{PENDAHULUAN}

Negara Indonesia merupakan negara yang memiliki berbagai macam dan beraneka ragam suku dan budaya. Hal ini menunjukkan bahwa Negara Indonesia kaya akan budaya yang dimiliki warganya di berbagai daerah. Keragaman budaya (multikultural) yang dibawa 
oleh individu maupun kelompok merupakan peristiwa alami yang lahir dari suatu interaksi, cara pandang yang berbeda maupun berlainan sehingga menghasilkan perilaku budaya dari individu dan kelompok tersebut dan menjadi suatu kebiasaan masyarakat di daerah setempat. Sehingga, keanekaragaman budaya yang dibawa oleh klien dari mulai agama, latar belakang hingga etnis yang berbeda menuntut konselor sebagai penyedia dan pembantu dalam pelayanan konseling untuk dapat memahami secara penuh akan budaya klien yang dibawanya (Matsumoto dalam Agus Akhmadi, 2017).

Dalam masyarakat multibudaya, perbedaan antara individu maupun kelompok merupakan suatu yang lumrah yang biasa terjadi dalam suatu kehidupan masyarakat apalagi di Negara Indonesia ini yang kaya akan budaya. Keragaman budaya seperti etnis, gender, latar belakang, geografis, ras, usia, kondisi fisik (Sue, \& Sue dalam Dody Riswanto, 2017) maupun keragaman suatu agama, karakteristik pribadi, sosial dan kemampuan intelektual (Redman dalam Dody Riswanto, 2017) merupakan keragaman yang fitrah dan umum terjadi dalam kehidupan.

Keragaman budaya yang dibawa oleh peserta didik sudah menjadi hal yang biasa dalam dunia pendidikan. Hal ini disebabkan oleh persebaran penduduk, dimana masyarakat berpindah tempat ke daerah lain dikarenakan beberapa alasan sehingga mau tidak mau penduduk tersebut menetap dan membawa budayanya ke tempat yang berbeda dalam mengenyam suatu pendidikan atau pekerjaan. Hal ini menjadi salah satu pengaruh yang dapat meningkatkan suatu ragam budaya konseli.

Guru BK (konselor) sebagai tenaga profesional dalam pelaksanaan konseling yang membantu konseli dalam memecahkan suatu masalah, dimana konselor tersebut bertanggung jawab secara penuh dalam pelaksanaan kegiatan konseling di sekolah. Konselor dituntut untuk memiliki keterampilan dan kompetensi-kompetensi secara khusus untuk melaksanakan tugasnya dengan optimal, salah satunya yaitu memiliki kompetensi multikultural atau konselor memahami keragaman budaya klien yang dibawanya.

Berbagai macam budaya klien dapat membuat guru BK (konselor) sadar akan pentingnya pengetahuan mengenai konseling multibudaya serta munculnya kesadaran multikultural dalam menghadapi suatu perbedaan sekecil apapun. Konselor seharusnya perlu mengubah mindset klien dengan mencukupkan pengetahuan tentang budaya, stereotip \& rasisme serta memahami betul akan bentuk diskriminasi (Holcomb-McCoy dalam Agus Akhmadi, 2013). Dalam proses layanan konseling di sekolah, guru bimbingan dan konseling harus memiliki kesadaran multikultural dimana konselor harus menghargai suatu perbedaan, keyakinan konseli, nilai, serta menyadari akan adanya bias-bias dan keterbatasan dalam diri 
klien mengenai hal budayanya. Dengan hal itu dapat memunculkan pemahaman pandangan hidup dan latar belakang budaya sehingga pengembangan strategi konseling sesuai dengan budaya klien.

Menurut Ratts et al (2015: 5-6) bahwa kompetensi konseling yang harus dimiliki oleh konselor yang adil secara sosial dan multikultural yaitu konselor yang memiliki selfawareness yang memuat attitudes and believe (Sikap dan keyakinan), knowledge (pengetahuan), skills (keterampilan), dan action (aksi). Kompetensi multikultural yang harus dimiliki salah satunya yaitu keterampilan konseling multibudaya. Menurut ACA (2005) guru BK (konselor) harus menjunjung tinggi akan kerahasiaan dan privasi klien yaitu dengan tetap mempertahankan sensitivitas dan kesadaran tentang makna budaya. Selain itu, Konselor harus menghormati pandangan dan nilai yang berbeda terhadap pengungkapan informasi.

Dalam perspektif teoritis, untuk menghadapi perbedaan dan keragaman budaya klien, konselor tidak cukup hanya dengan penggunaan pendekatan konvensional, karena hal itu kurang efektif dan optimal ketika melayani klien dengan etnis yang beragam. Tuntutan terhadap kesadaran multikultural yang ditujukan kepada tenaga konselor semakin relevan dengan telah disahkannya profesi konselor (guru BK) sebagai tenaga atau profesi yang harus memiliki keterampilan dan kualifikasi profesional yang dibutuhkan untuk melayani dan memenuhi kebutuhan konseli yang beragam karakteristik dan budayanya, terampil dan mampu berkomunikasi secara efektif, mendengarkan sepenuh hati dengan penuh perhatian dan empati, terampil dalam pengungkapan diri dan pemahaman informasi pribadi (Hayden Davis, dalam Agus Akhmadi, 2013).

Selanjutnya dalam Permendikbud Tahun 2014 Nomor 111 menyatakan bahwa bimbingan dan konseling diperuntukkan bagi semua kalangan tanpa diskriminatif. Artinya layanan diskriminatif disini yaitu layanan bimbingan konseling yang harus berempati terhadap klien tanpa membedakannya. Hal ini mengarah dan berkaitan pada budaya di negara Indonesia sendiri, dimana keragaman budaya membutuhkan layanan yang sejalan dengan nilai-nilai multibudaya sehingga terciptanya keharmonisan dalam pelaksanaan layanan.

Bemak (2005) menyatakan prihatin atas kemampuan/kompetensi guru BK terhadap konseling multibudaya dengan alasan pada saat praktik layanan kurang maksimal dan efektif. Hal itu ditunjukkan dari konselor sendiri yang mengabaikan keragaman budaya, nilai-nilai yang berbeda yang mereka anut, perbedaan bahasa, latar belakang keluarga, agama, pandangan hidup klien dan lainnya. Dengan hal tersebut dapat mendorong perlunya guru bimbingan dan konseling untuk dapat menjadi tenaga yang berkompeten dalam praktik layanan konseling (Agus Akhmadi, 2017). 
Sejalan dengan penelitian yang dilakukan oleh Agus Akhmadi mengenai kompetensi konseling multibudaya guru BK Madrasah Aliyah Jawa Timur, dimana menunjukkan bahwa $60 \%$ kompetensi guru BK MA rendah dalam aspek pengetahuan terhadap konseling multibudaya serta $40 \%$ kesadaran konselor akan konseling multibudaya. Dari aspek pengetahuan yang rendah di tunjunkkan dari, a) kurangnya pengetahuan konselor terhadap individu bahwa tidak semua individu mampu bertanggung jawab akan dirinya sendiri, b) kurang mengetahuinya konselor tentang teknik konseling yang tidak semuanya efektif diberikan kepada beragam konseli, c) tidak semua konseli dapat melakukan eyes contact dalam konseling, hal ini konselor kurang mengetahuinya, d) kurangnya konselor dalam mengetahui proses konseling tidak semuanya memiliki pandangan kompetitif dan mengarah pada prestasi.

Menurut Yusuf, dkk (2007) bahwa kompetensi guru BK perlu ditingkatkan karena secara umum kompetensi ini termasuk kategori tinggi. Dengan hal tersebut, yang perlu ditingkatkan konselor yaitu pengetahuan dan keterampilan konseling lintas budaya, pandangan hidup dan value, bahasa dan stereotype maupun bias budaya. Selain itu, menurut Wibowo (2015) pengetahuan mengenai multibudaya merupakan hal yang penting sehingga dapat memberikan pelayanan yang efektif terhadap konseli yang memiliki beragam budaya. Dengan hal tersebut dapat digunakan oleh guru bimbingan dan konseling untuk memprediksi konselinya sebagai awal dalam intervensi selanjutnya. Dalam penelitian terdahulu yang dilakukan oleh Nugraha Agung (2017) berkenaan dengan rendahnya wawasan konselor akan multibudaya diakibatkan oleh karakter konselor sendiri dan hal ini dapat kurang efektif saat dalam proses konseling.

Berdasarkan hal tersebut, peneliti mengangkat judul "Pengetahuan dan keterampilan guru BK Mengenai Konseling Multibudaya di Indonesia” dengan tujuan untuk mengetahui sejauh mana pengetahuan dan keterampilan guru BK dalam konseling multibudaya. Selain itu juga mengingat pentingnya pengetahuan dan keterampilan guru BK dalam konseling multibudaya/multikultural serta rendahnya pengetahuan dan keterampilan tersebut, maka secara khusus perlunya peningkatan dalam hal itu.

\section{METODE}

Jenis penelitian ini menggunakan pendekatan kualitatif dengan desain studi eksplorasi. Penelitian eksplorasi disini bertujuan untuk memperdalam pengetahuan dan mencari ide-ide baru mengenai suatu gejala tertentu, menggambarkan fenomena sosial, dan menjelaskan 
bagaimana terjadinya suatu fenomena sosial untuk merumuskan masalah secara lebih terperinci.

Teknik pengambilan data diperoleh melalui angket dengan google form yang disebarkan melalui whatsapp group untuk mengetahui pengetahuan dan kompetensi guru BK mengenai konseling multibudaya. Angket terbuka yang disebarkan ini dilakukan terhadap beberapa narasumber yaitu perwakilan guru BK di beberapa provinsi di Indonesia yang terdiri dari Jawa Timur yang diwakilkan oleh 2 orang guru BK, Jawa Tengah yang diwakilkan oleh 1 orang guru BK, Jawa Barat yang diwakilkan oleh 1 orang guru BK, Makassar yang diwakilkan oleh 1 orang guru BK, Sulawesi Selatan yang diwakilkan oleh 1 orang guru BK, Kalimantan Utara yang diwakilkan oleh 1 orang guru BK dan Nusa Tenggara Barat yang juga diwakilkan oleh 1 orang guru BK untuk memperoleh data yang sifatnya umum. Sehingga, total sumber penelitian dalam hal ini yaitu 8 guru BK dari beberapa provinsi yang dijadikan sebagai informan.

\section{HASIL}

Proses penelitian dengan studi eksplorasi ini menghasilkan beberapa jawaban dari hasil angket yang dikemas dalam bentuk google form. Dimana hasilnya dari 8 guru BK yang diwakilkan dari beberapa provinsi menunjukkan semua informan (guru BK) merupakan lulusan S1 bimbingan dan konseling dengan lama mengajar dimulai dari 9 bulan, 6 tahun, 7 tahun, 10 tahun dan 14 tahun.

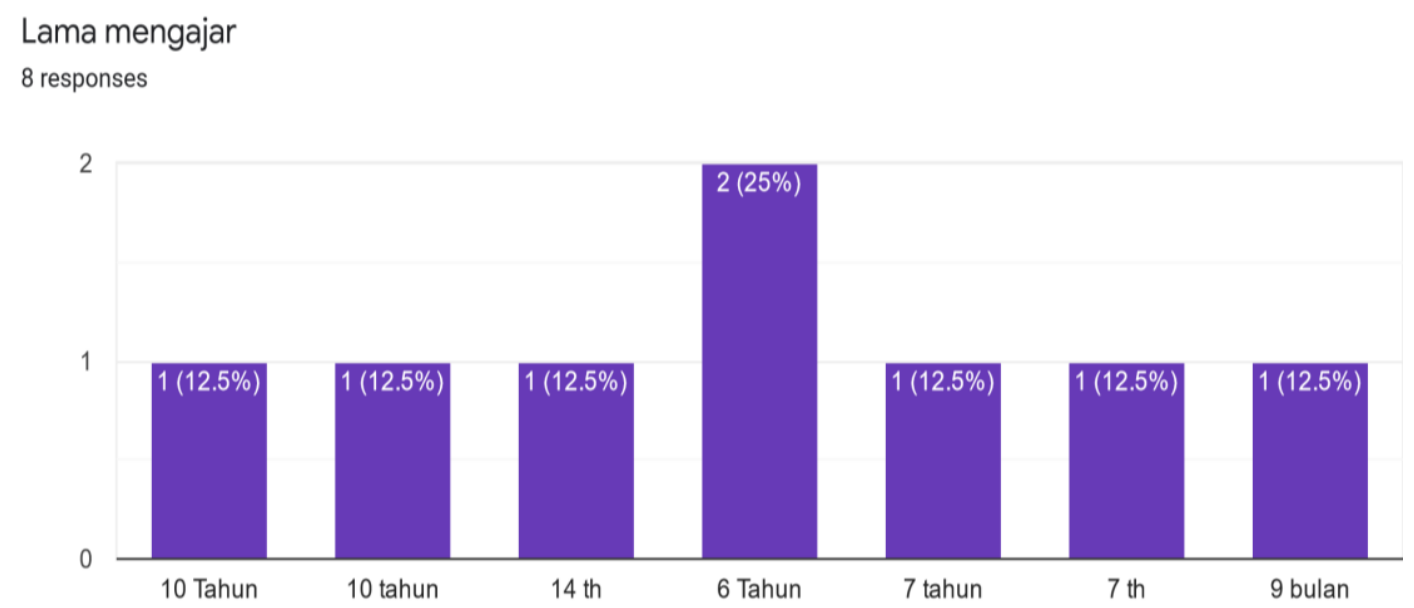

Grafik 1.1. Lama mengajar guru bimbingan dan konseling di sekolah 
Keterampilan konseling dari pelaksanaan kegiatan konseling banyak digunakan oleh guru BK yang menunjukkan $87,5 \%$ dan yang tidak menggunakan yaitu sebesar $12,5 \%$. Dari hasil yang menjawab (iya) keterampilan konseling yang banyak digunakan yaitu berupa atteending, empati, refleksi, eksplorasi, paraphrashing, opened question, closed question, interpretasi, directing, summarizing, leading, konfrontasi, facilitating, menyimpulkan, merencanakan, accepting, advice dan lain sebagainya. Sedangkan yang tidak menggunakan keterampilan konseling dengan alasan respon siswa tidak sesuai dengan yang diharapkan sehingga akhirnya membutuhkan waktu yang lama yang biasanya bisa lebih singkat. Selain itu karena ingin mempersingkat waktu pada saat kegiatan konseling.

Apakah Bapak/lbu menggunakan keterampilan konseling ketika pelaksanaan konseling berlangsung dengan klien?

8 responses

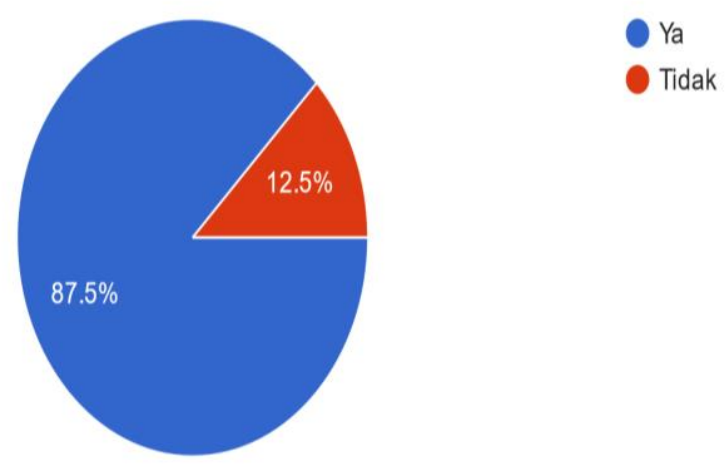

Grafik 1.2. Penggunaan keterampilan konseling guru bimbingan dan konseling

Untuk pengetahuan dan keterampilan guru BK mengenai konseling multibudaya dari 8 guru BK di beberapa provinsi, hanya ada 3 orang guru BK yang mengetahui keterampilan konseling multibudaya serta penerapannya dan 5 responden kurang tahu mengenai konseling multibudaya. Sehingga dari hasil angket tersebut bisa dikatakan informan banyak yang kurang tahu atau rendahnya pengetahuan dan keterampilan konselor berkenaan dengan konseling multibudaya, sehingga hal ini tidak bisa diterapkan pada saat pelaksanaan konseling berlangsung karena kurang memahaminya konselor mengenai keterampilan konseling multibudaya tersebut. Padahal mereka menganggap bahwa konseling multibudaya ini sangat penting diketahui oleh guru bimbingan dan konseling karena dapat membantu memahami klien dan mendukung kepiawaian konselor dalam menangani klien sesuai kondisi sosial dan budaya konseli. 


\section{PEMBAHASAN}

Konseling multibudaya adalah konseling yang baru populer 20 tahun belakangan ini. Locke (Nuzliah dalam Muhammad Yusuf, 2016) mendefinisikan bahwa konseling multibudaya ini adalah sebagai salah satu bidang praktik dalam kegiatan konseling yang menekankan pentingnya dan keunikan (kekhasan) individu, nilai-nilai pribadi yang dibawa oleh konselor dan konseli yang berasal dari tempat yang berbeda sehingga menghasilkan latar belakang budaya, ras, serta suku yang juga ikut berbeda sehingga mencerminkan latar belakang daerah asal yang dibawa ke dalam seting konseling.

Secara resmi pada tahun 1960 dan 1970-an dikembangkan kegiatan konseling yang di peruntuhkan untuk klien yang membutuhkan kesadaran, pengetahuan, dan keterampilan yang berbeda dari tradisi profesi. Banyak tokoh pemikir barat seperti Carls Rogers, Albert Ellis, dan Fritz Pels, menyatakan bahwa budaya orang kulit berwarna secara kualitatif berbeda dari budaya kulit putih. Oleh karena itu validitas teori dan teknik di dasarkan pada tradisi budaya yang harus dipertanyakan ketika diterapkan interaksi konseling dengan orang kulit berwarna pada saat proses konseling.

Berdasarkan hasil penelitian di atas berkenaan dengan pengetahuan dan keterampilan guru BK mengenai konseling multibudaya yang rendah, sangat berdampak terhadap penerapanya terhadap siswa. Dalam hal itu, seharusnya guru BK tentu harus memiliki skill berkenaan dengan hal tersebut, mengingat siswa/klien memiliki dan membawa budayanya masing-masing yang tentunya berbeda-beda. Kemudian, dalam penelitian yang dilakukan oleh Khusnul Khowatim (2020) mengenai peran konselor dalam konseling multibudaya untuk mewujudkan kesetaraan gender menyatakan bahwa pemahaman konselor akan pengetahuan dan keterampilan terhadap konseling multikultural dapat mengantarkan konselor untuk menyadari hal atau keterampilan apa saja yang perlu dimiliki atau mungkin perlu dikembangkan agar dapat memaksimalkan terselenggaranya konseling multikultural yang efektif sesuai dengan prinsip bimbingan dan konseling. lebih lanjut karakteristik konselor yang efektif secara kultural juga akan sangat mempengaruhi keterampilan konselor dalam praktik layanan konseling multikultural yang tidak dapat muncul begitu saja dalam diri konselor, namun perlu latihan dan evaluasi secara berkelanjutan dan berkesinambungan.

Menurut Arredondo, Hays dan Erford, Baruth \& Manning, Sue \& Sue, Nugraha dalam E. R. Kusmaryani, (2010) tentang keterampilan maupun kemampuan multibudaya yang harus dimiliki konselor sebagai berikut:

1. Konselor memiliki kesadaran mengenai budayanya sendiri serta bias akan budayanya (awareness of own cultural values and biases), indikatornya sebegai berikut: 
a) Perilaku dan kepercayaan konselor

1) Konselor dapat menyadari keterbatasan akan kemampuan/kompetensi multibudaya yang dimilikinya.

2) Konselor dapat menyadari bahwa latar belakang budaya dapat berpengaruh terhadap nilai, perilaku/sikap dan polemik proses psikologi.

3) Ketidaknyamanan harus disadari konselor yang bersumber dari perbedaan budayanya dengan konseli.

4) Pentingnya konselor dalam menyadari kepekaan warisan dan nilai budaya yang merupakan hal penting dalam kegiatan konseling.

b) Pengetahuan

1) Konselor dapat mengetahui bahwa antara bahasa/gaya komunikasi pada proses konseling dapat melahirkan dampak dan perbedaan.

2) Konselor dapat mengetahui pengetahuan yang luas yaitu polemik normalitas, abnormalitas, proses konseling serta mengenai warisan budaya dan pengaruhnya, baik dari segi pribadi maupun profesional.

3) Konselor memiliki pengetahuan tentang dampak sosial dirinya terhadap kliennya.

4) Secara pribadi maupun profesional, konselor dituntut memiliki pengetahuan mengenai diskriminasi, pengaruh ketidakadilan, rasisme, dan persamaan.

c) Keterampilan

1) Konselor sadar akan kemampuan dirinya, sehingga konselor dapat menggali lebih mendalam pelatihan atau pendidikan lanjutan yang menunjang kompetensi dalam konseling multibudaya, dapat mencari konsultasi dan mereferal konseli kepada tenaga ahli yang lain.

2) Konselor dapat banyak berlatih dengan konseli yang memiliki budaya yang berbeda sehingga menghasilkan pengalaman dari pelatihan tersebut dan dapat berdampak positif bagi kemampuan dirinya.

3) Konselor dapat memahami identitas dirinya sebagai makhluk hidup yang memiliki suku, budaya, etnik, dan ras.

2. Konselor dapat memahami pandangan hidup konseli yang berbeda dengannya (awareness of client's world view)

a) Perilaku dan kepercayaan konselor

1) Konselor lebih berani dalam mempertentangkan perilakunya dengan konseli yang memiliki latar budaya yang berbeda tanpa adanya penghakiman. 
2) Sadarnya konselor dengan adanya stereotipe dalam kelompok minoritas, etnik, ras, suku, serta budaya klien.

3) Konselor dapat menyadari bahwa emosional yang mengarah ke arah negatif yang dimilikinya terhadap budaya konseli mungkin dapat membahayakan konseli dalam proses konseling.

b) Pengetahuan

1) Konselor dapat menyadari latar belakang budaya, warisan dan pengalaman hidup yang berbeda dengan konseli.

2) Pengetahuan yang cukup luas konselor mengenai kelompok yang dapat diajak untuk bekerjasama yang dapat membantu dirinya.

3) Informasi mengenai pengaruh sosial politik terhadap kelompok minoritas etnis dan ras harus dimiliki konselor.

c) Keterampilan

1) Konselor dapat memiliki keterampilan aktif bergabung terhadap kaum minoritas dalam kegiatan masyarakat, tetangga, perayaan dan lain sebagainya diluar seting konseling.

2) Konselor dapat familiar dengan kelompok ras dan etnis dengan penemuan terbaru mengenai gangguan dan kesehatan mental .

3) Konselor dapat lebih aktif dalam menggali pengetahuan dan pemahaman sehingga dapat memperkaya kemampuannya dalam konseling multibudaya.

3. Konselor mampu mengembangkan strategi dan intervensi budaya yang tepat (culturally appropriate intervention strategie)

a) Perilaku dan kepercayaan konselor

1) Konselor mampu menghargai bilingualisme perbedaan bahasa konseli sehingga tidak menghambat proses konseling.

2) Value spiritual dan religius konseli harus mampu dihargai oleh konselor.

3) Konselor mampu menghargai kinerja pembantu dan kealamiannya bagi masyarakat kelompok minoritas.

b) Pengetahuan

1) Konselor memiliki pengetahuan khusus dan jelas mengenai konseling multibudaya (monolingual, ikatan budaya, nilai budaya dan ikatan kelas).

2) Konselor dapat memiliki pengetahuan mengenai nilai, hirarki, kepercayaan keluarga dan karakteristik masyarakat. 
3) Konselor mampu mengetahui potensi polemik dalam menilai suatu instrumen menggunakan prosedur serta dapat menginterpretasikannya ke dalam bahasa yang sesuai dengan budaya konseli yang berbeda.

c) Keterampilan

1) Konselor dapat lebih aktif dalam keterlibatannya dalam beragam respon verbal maupun non verbal serta dapat menerimanya dengan akurat dan sesuai.

2) Konselor dapat memodifikasi teknik atau pendekatan yang diberikan kepada konseli sehingga tidak terikat hanya pada satu metode tetapi pendekatan bisa berupa atau terikat pada budayanya sendiri (budaya konseli).

3) Konselor memiliki keterampilan untuk tidak menolak bantuan orang lain salah satunya pemimpin religius dan penyembuh tradisional serta praktisi lainnya yang memiliki budaya yang berbeda.

4) Konselor dapat bertanggung jawab dan mampu untuk dapat berinteraksi dengan konseli menggunakan bahasa konseli, jika konselor tidak mampu dan tidak memiliki keterampilan dalam hal tersebut, maka konselor dapat mereferal dan meminta bantuan kepada penerjemah dengan pengetahuan budaya dan latar belakang yang profesional serta mencarikan konselor bilingual yang berkompeten.

5) Konselor mampu dalam penggunaan assessment dan instrumen dengan aktif dalam mengikuti pelatihan sehingga konselor dapat memahami teknik instrumen tetapi juga dapat memahami batasan budaya dalam penggunaan instrumen tes.

6) Dalam pelaksanaan evaluasi, konselor harus menyadari konteks sosial politik, mengembangkan sensitivitas terhadap rasisme, sukuisme, seksisme dan ketidakadilan serta menyediakan intervensi.

7) Saat melakukan intervensi konseling, Konselor mampu bertanggung jawab dalam mendidik konseli dengan tujuan, orientasi dan harapan.

Sue dan kawan-kawan mengusulkan sejumlah kompetensi minimum yang harus dimiliki guru BK (konselor) yang memiliki wawasan lintas budaya, diantaranya yaitu; 1) keyakinan dan sikap konselor yang efektif secara kultural, 2) pengetahuan konselor yang efektif secara multikultural, 3) keterampilan konselor yang efektif secara kultural. Hal ini mengingat akan pentingnya dan urgensi peran budaya dalam proses kegiatan konseling serta beragamnya budaya yang ada di Indoenesia sendiri dalam upaya memaksimalkan konseling, maka disini konselor perlu memahami bantuan atau intervensi yang berwawasan lintas budaya dalam konseling. 
Pengetahuan guru bimbingan dan konseling mengenai pentingnya konseling multibudaya ini merupakan sebuah kompetensi yang harus dimiliki oleh konselor untuk mengatasi masalah yang lebih luas dari keanekaragaman budaya klien. Hal ini menjadi catatan penting dan PR bagi konselor mengingat keberagaman budaya yang dibawa oleh klien sangat beragam terutama di Indonesia sendiri. Dengan demikian, seorang konselor harus memiliki pengetahuan secara khusus mengenai teknik konseling dan sosial budaya, sikap terbuka dan toleran terhadap perbedaan klien, serta keterampilan dalam memodifikasi teknik-teknik konseling yang akan digunakan pada saat proses konseling secara efektif dalam latar budaya yang berbeda. Menyangkut hal tersebut konselor Indonesia juga perlu memahami ciri-ciri khusus budaya dan sub budaya dari bangsa Indonesia yang beraneka ragam serta mampu menjadikan keanekaragaman tersebut sebagai unsur pemersatu dalam kehidupan berbangsa dan bernegara di Indonesia.

\section{SIMPULAN}

Berdasarkan penelitian di atas, pengetahuan dan keterampilan konselor mengenai konseling multibudaya masih rendah. Guru bimbingan dan konseling kurang mengetahui budaya konseli dan lebih menyamaratakan dengan budayanya. Sehingga hal ini berimbas pada konseli saat pelaksanaan proses konseling.

Konseling multibudaya merupakan proses interaksi antara konselor dengan konseli dengan latar belakang yang berbeda budaya sehingga hal ini diperlukan pemahaman terhadap konsep dan budaya lain terutama bagi konselor agar dapat memberikan bantuan atau layanan secara efektif dan optimal sesuai dengan perspektif budaya konseli. Untuk dapat memberikan pelayanan konseling yang baik dibutuhkan pengetahuan dan keterampilan/kompetensi secara khusus mengenai konseling multibudaya yang harus dimiliki oleh konselor. Konselor perlu memahami karakter budaya dari konseli, serta dapat merancang segala tindakan dalam perspektif budaya konseling.

Selain itu, ada beberapa kompetensi yang harus dimiliki oleh konselor dalam konseling multibudaya, diantaranya yaitu:

1. Konselor memiliki kesadaran mengenai budayanya sendiri serta bias akan budayanya (awareness of own cultural values and biases)

2. Konselor mampu dapat memahami pandangan hidup konseli yang berbeda dengannya (awareness of client's world view)

3. Konselor mampu mengembangkan strategi dan intervensi budaya yang tepat (culturally appropriate intervention strategie) 
Dari tiga kompetensi di atas, tentu konselor juga harus meng-update kompetensikompetensi budaya yang lain agar konselor dapat menyelesaikan permasalahan konseli dengan optimal. Apalagi konselor merupakan ujung tombak serta memiliki peran utama dan signifikan dalam pelaksanaan layanan konseling, dimana kemampuan konselor sangat dibutuhkan dalam menyelesaikan permasalahan konseli sehingga konselor memiliki tanggung jawab dan tugas yang cukup besar. Dengan beragamnya dan luasnya determinasi budaya yang dibawa konseli, maka hal ini merupakan tugas penting guru bimbingan dan konseling (konselor) untuk lebih menggali informasi yang mendalam yang mengarah pada kemampuan dirinya dalam melakukan konseling multibudaya.

Mengacu dari hasil penelitian di atas, maka disarankan kepada guru BK (konselor) untuk dapat lebih meningkatkan kemampuan serta keterampilan konseling lintas budaya agar kompetensi-kompetensi yang diharapkan dapat dimiliki sehingga proses konseling lebih efektif dan optimal. Konselor dapat belajar secara khusus serta mencari tahu lebih jauh akan pengetahuan dan kemampuan konseling multibudaya mengingat klien datang dari berbagai daerah yang memiliki latar belakang budaya yang berbeda dan bermacam-macam. Selain itu, kepada akademisi maupun pengampu kebijakan bimbingan dan konseling untuk lebih banyak menyediakan praktik pelatihan (workshop) konseling multibudaya bagi guru bimbingan dan konseling (konselor) dalam rangka penambahan pengetahuan kompetensi konselor.

\section{DAFTAR RUJUKAN}

Akhmadi, Agus. 2013. Peningkatan Kesadaran Multikultural Konselor (Guru BK). MUADDIB Vol. 03, No. 02.

Akhmadi, Agus. 2017. Kompetensi Konseling Multibudaya Guru BK Madrasah Aliyah Jawa Timur Alumni Diklat BDK Surabaya. Jurnal Diklat Keagamaan, Vol. 11, No. 1.

Aqwal, Shadiqatunil, dkk. 2020. Pelayanan Konseling Multibudaya Di Pondok Pesantren. Ristekdik (Jurnal Bimbingan dan Konseling). Vol 5, No. 1.

Erlamsyah, 2017. Konseling Multibudaya di Sekolah. Prosiding Semarak 50 Tahun Jurusan BK FIP UNP, Seminar Konseling \& Talkshow Nasional, 22 April.

Khowatim, Khusnul. 2020. Peran Konselor dalam Konseling Multibudaya untuk Mewujudkan Kesetaraan Gender. Jurnal Bikotetik, Vol 04, Nomor 01.

Kusmaryani, E. R. 2010. Penguasaan Keterampilan Konseling Guru Pembimbing di Yogyakarta. Jurnal Kependidikan, Volume 40, Nomor. 2.

Miskanik. 2018. Penggunaan Konseling Multikultural dalam Mendorong Perkembangan Kepribadian Anak Berkebutuhan Khusus (ABK). Sosio e-kons, Volume 10, No. 3.http://journal.lppmunindra.ac.id/index.php/sosio_ekons.

Mudjiyanto, Bambang. 2018. Tipe Penelitian Eksploratif Komunikasi. Jurnal Studi Komunikasi dan Media Vol. 22 No. 1

Nugraha, Agung, dkk. 2017. Kepekaan Multibudaya Bagi Konselor Dalam Layanan Konseling. Journal of Innovative Counseling: Theory, Practice, \& Research. Vol. 1, No. 1. 
Riswanto, Dody. 2017. Kompetensi Multikultural Konselor Pada Kebudayaan Suku Dayak Kalimantan Tengah. JOMSIGN: Journal of Multicultural Studies in Guidance and Counseling, Volume 1, No. 2.

Setyaputri, Y. N. 2017. Karakter Ideal Konselor Multibudaya Berdasarkan Nilai Luhur Semar. Jurnal Kajian Bimbingan dan Konseling, 2 (2).

Subandi. 2011. Deskripsi Kualitatif sebagai Satu Metode dalam Penelitian Pertunjukan. Harmonia, Volume 11, No. 2.

Yusuf, Muhammad. 2016. Konseling Multikultural sebuah Pradigma Baru untuk Abad Baru. Al-Tazkiah, Volume 5, No. 1. 